\title{
Homo sociologicus and the Society of Individuals*
}

\author{
JIŘÍ ŠUBRT**
}

Homo sociologicus a problém společnosti individuí

\begin{abstract}
The present article follows the themes treated in "The Society of Individuals: How to Solve the Dilemma of Individualism and Holism in Historical Sociology" published in the journal Historická sociologie No. 1/2015. Its primary topic is social roles, a theme actively discussed in sociological literature from the 1950 s to the 1980 s but afterwards largely neglected because the concepts of individual human actors (agents) and their actions (agency) pushed the topic of roles to the sidelines. This article tries to show that despite this intellectual shift, the theme of social roles deserves attention even today, and in particular that the concept of "role playing" can be useful in sociological theory to resolve the seemingly irreconcilable opposition of individualistic and holistic approaches.
\end{abstract}

Keywords: sociological theory; social role; role playing; actor; structure; function; individualism and holism

DOI: $10.14712 / 23363525.2017 .36$

In the present article we aim to continue with, and further elaborate on, the issues dealt with in "The Society of Individuals: How to Solve the Dilemma of Individualism and Holism in Historical Sociology", published in the journal Historická sociologie in No. 1/2015. To begin, let us recall that the basis of this study was the idea formulated by Norbert Elias in his book The Society of Individuals: the claim that Western thought is divided into two camps [Elias 2006: 68]. Throughout sociological thinking, and historically dating from its very outset, we encounter two opposing intellectual convictions that are very difficult to harmonize. The representatives of individualism consider the starting point of sociological thinking to be human individuals (a position originating in Max Weber). The supporters of holism by contrast claim that the starting point must be the collective entity of society itself (the position of Emile Durkheim). ${ }^{1}$ Elias's crucial question asked how this gap could be bridged to overcome the contradiction between these two positions.

In the above-mentioned article [Šubrt 2015], the solution to this problem was connected with Elias' concept of "figurations", adding the idea that social action and social

This study was written within the framework of the project "Homo Sociologicus Revisited" (No. 15-14478S) supported by the Czech science foundation GAČR.

** Doc. PhDr. Jiří Šubrt, CSc., Department of Historical Sociology, Faculty of Humanities, Charles University. U Kř́že 8, 15800 Praha 5. E-mail: jiri.subrt@fhs.cuni.cz.

1 Both positions - individualistic and holistic - represent viable research strategies, worked out through many sociological schools and directions during the 20th century. The individualistic approach can be found in exchange theory and rational choice theory, but also in interpretive sociology (phenomenological sociology, biographical approaches). As outcomes of holism, we find primarily structuralism, functionalism and systems theory. However, several exploratory approaches additionally emerged in the 20th century, viewing both these tendencies as one-sided and limited, and attempting to overcome them by bridging or linking them [Parsons (1937) 1966; Berger - Luckmann 1999; Habermas 1981; Giddens 1997; Bourdieu 1998]. 
structures are "duplex". The formulation and elaboration of this "duplex" idea was inspired by reflections on the ambivalent nature of the human being (under the designation "homo duplex"). In this new article, we focus on the problem of Society of Individuals again, but from a different angle - from the perspective offered by the sociological concept of roles.

As a starting point, we should recall that in the late 1950s, Ralf Dahrendorf wrote a study entitled Homo sociologicus. Although many decades old, this work presents ideas that still remain relevant, and definitely deserve a place in sociological analysis. Dahrendorf argues that the foundations of several different social sciences rest upon the unspoken assumption of a simplistic character of the human subject. In economics, we find for example the idea of homo oeconomisus, according to which the human being always acts to achieve the maximum profit at minimum cost. In political science, there is the idea of homo politicus, presenting the individual subject exclusively as a voter who prefers the political party which - in his opinion - will represent the interests of his society in the best way. In sociology, the unspoken prerequisite is the conception of the human being as an entity that plays (enacts, embodies) social roles, which Dahrendorf dubbed homo sociologicus [Dahrendorf 1964].

The topic of social roles became popular in the 1960s and 1970s through a number of different conceptions and theoretical backgrounds. In the following text we focus on approaches to the social role that can be considered vital and fruitful even from the current point of view. In the conclusion of this text, we attempt to show why even today a return to the theme of social roles could prove both sensible and feasible.

\section{Basic approaches and thematic areas}

The textbook definition of social role was initially formulated by Ralph Linton [Linton (1936) 1964: 113-114] as a set of "expectations" related to individual behaviour which occupies a certain "status" (position) in society. "Expectations", as a category, defines not only the role but its status. Status, in turn, is defined by what a person in a certain position in society can expect from others, who in return can themselves lay claims and impose demands. It should further be noted that the term "expectation" has a significant connection to the problems of structures, understood as the principles and rules that arrange and formulate social reality.

As an anthropologist, Linton was interested specifically in communities where these "expectations", and thus also structures, had not yet acquired definitively codified form. In contemporary societies, by contrast, many roles, especially in a variety of organizational systems, are defined by organizational regulations, implicit norms, and sometimes even state-imposed laws.

An important contribution to the formulation of the idea of the social roles was offered by George Herbert Mead [1977: 209-246] and his theory of the human "Self" as uniting two components, "I" and "Me". "I" is an individual, subjective component that is active and creative. "Me" is an objective, passive component based primarily on the internal attitudes of the social group or society to which the individual belongs. In Mead's concept, which became part of the theory of symbolic interactionism, and later even of social constructionism [Berger - Luckmann 1999], the learning of social roles forms a major part of the socialization process. 
Psychologist and psychiatrist Jacob Levy Moreno contributed to the popularity of the concept of the role in human sciences. Nonetheless, he devoted relatively little attention directly to the sociological aspects of social roles, as his main theme was spontaneous role-playing as a therapeutic tool within psychodrama, i.e. a method of group therapy inspired by theatrical improvisation (note his first major work on this topic published in 1946 [Moreno 1977]). In sociology, Erving Goffman has been associated with the adjective "dramaturgical", because for Goffman, both in the theatre and in society, we are presented with a series of performed encounters with various individuals who engage in enactments for other people to make an impression. In his book The Presentation of Self in Everyday Life (1959 [Goffman 1999]), he focuses on dramaturgical aspects in the behaviour of social (explicitly as opposed to stage) actors, using such metaphorical concepts as "performance", "role", "dramatization", "staging", "stage set" and "backstage". Later the relationship between theatrical environment and social realities was addressed by other authors [see e.g. Langer 1980; Eisermann 1991: 19-40].

One aspect usually omitted from the textbook interpretation of the issue of roles is the elaborated concept of roles put forth in a joint study by Hans Gerth and C. Wright Mills, Character and Social Structure, published as early as 1953 [Gerth - Mills 1970]. Combining influences from Marx, Weber, Freud and Mead, their approach is strongly oriented towards social psychology. However, the contemporary mainstream of American sociology was then considerably different, being dominated by the structural functionalist concept, which enriched reflections on roles with a macro-sociological view.

If we turn to consider this functionalist perspective, we can put forth the following differentiation that it provides: while the term "function" expresses the specific contribution of different social components (organizations and subsystems) to the maintenance of society as a whole, the concept of "role" expresses how human individuals contribute to the same task. Essentially, the social role is a kind of conceptual bridge between the human subject's individual and social functions. Or - put more radically - "through roles the social system empowers individuals and their activities and uses them for its effective functioning" [Urbánek 1979: 104]. A similar perspective is found in Kingsley Davis and Wilbert Moore, who explain from functionalist positions why we see social inequality everywhere [Davies - Moore 1945]. Simply to ensure its reproduction and perpetuation, society must ensure the implementation of certain necessary functions. The securing of this task, in turn, lies in the hands of individuals operating respectively through organizations and subsystems to perform the social roles endorsed by them. According to Davis and Moore, if society is to ensure that the most important social functions are carried out by the most qualified individuals, it is necessary to have an unequal system of remuneration, in which those individuals who perform the most important tasks receive the highest payments.

Setting aside the numerous polemical voices justifiably raised against Davies's and Moore's conclusion, we can say that the functionalist approach draws attention to issues of social distribution and the allocation of roles. Functionalist interpretative models are associated with the evolutionary concept of functional differentiation, which analyzes how social entities, institutions, and their respectively issued social roles provide differentiation based on the principle of Durkheim's classical division of labour toward ever greater complexity and higher specialization. Simultaneously, they deal with how functionally differentiated complex units reproduce over time, how they remain held together, and 
also how they may end in disintegration, or even in explicitly pathological phenomena. Of great importance in this context are the concepts of dysfunction and anomie elaborated by Robert K. Merton [2000: 132-177]. In Lundberg, Schrag and Larsen [1969: 358] we can see evidence of how the concept of "roles" can be associated with dysfunctional and anomic phenomena, an insight used especially by criminology to assess patterns of behaviour exhibited by thieves, fraudsters or prostitutes.

Furthermore, Merton contributed to the legacy of thought in this field with his concept of "role-set", a term interpreted variously by later textbooks. Merton himself laid the groundwork for these interpretations through his assertion that each status in society is bound up with multiple roles [Merton 1977: 68], and identifying the complements of role relationships attained by a person occupying a certain social position. Essentially, different people in different positions expect different things from one and the same role. A professional role may be enacted differently by senior executives than by their subordinates, and in a still different way toward the public, thus associating the set role of "professional" with a range of expected manifestations that may sometimes diverge significantly. Increasingly, in current sociological literature we also come across the term "repertoire".

Nonetheless, among the functionalist social thinkers who addressed this topic, it was predominantly Talcott Parsons for whom the concept of role emerged as one of the main categories of social structure, with the application of a structuralist perspective and the understanding of structure as a network of relationships between actors of interactive processes that established formulas of relationships between acting persons [Parsons 1968: 54]. This network is formed by roles, institutionalized norms and values, where roles represent essential structural units.

In his The Social System, Parsons speaks about the system of differentiated roles as a structure in the strict sense [Parsons (1951) 1966: 114]. Sets of roles are created by institutions, which themselves form higher-order structural units. As the institutions represent complementary sets of regulations, the norms and roles that they produce are important for the operation of a given system, and as such are required and expected of individual actors. Included within the structure is also the question of allocation, i.e. the allocation of limited supplies among structural units. As roles are critical, some of them vitally so, the first aspect of allocation is the issue of the occupation of the roles, i.e. the division of individuals into their necessary roles, along with the distribution of resources and rewards.

At the heart of Parsons' analysis stands the imperative of consensus, i.e. the functional integration and stability of the social system, ensured by the compliance of the behaviour of individual actors with established patterns of behaviour (role-expectations) and value orientations. Achieving equilibrium and stability in social systems is ensured by built-in mechanisms of adaptation and control. Parsons emphasizes the conformity of individuals to roles and the social system, and stresses in parallel the need to eliminate deviant phenomena and conflicts from society.

If Parsons was a key representative of consensus theory in sociology in the 1950s and 1960s, one of the most important representatives of the opposing group, represented by theories of conflict, was the German sociologist Ralf Dahrendorf. Among his major achievements is the creation of a typology of social conflicts, with one type situated at the level of social roles [Dahrendorf 1963: 206]. Since Dahrendorf's list of possible types 
of conflicts associated with social roles has become a standard part of various textbooks, this topic requires only a brief mention. The most commonly reported cases include the following:

- Conflicts among roles, stemming from the need for every individual to play not just one but several roles. These diverse roles can place significant demands in terms of time and performance, but may also be associated with conflicting expectations [Dahrendorf 1964: 59].

- Conflicts can arise from inconsistent expectations attached to a particular role in at least two cases. In the first, contradictory expectations come from various actors who play differing complementary roles (e.g. the requirements of senior executives against the ideas of subordinates [Lundberg - Schrag - Larsen 1967: 358]). In the second, mutually incompatible and inconsistent expectations are issued to a single actor in a single role (e.g. a woman in a romantic relationship expected to be both sexually responsive and chaste).

- Finally, conflicts can concern the relationship between the role and the personality of the actor who is to play it, in the event that the role attributed to the individual does not suit them for some reason, or is even against their conscience [see e.g. Dreitzel 1980; Junker 1971]. The reasons for this may be mainly psychological (the individual does not feel adequately equipped for the performance of the role) or ethical (the role is unacceptable to them).

Social roles are often associated with the distribution of power: i.e., the ability to force someone to play some kind of role, assign them to a role of subordinate position, and conversely to benefit from self-selected roles in superior positions. The relationship of role and power has become a subject of specialized studies [Claessens 1970; Schulte-Altedorneburg 1977; Wiswede 1977: 57-77], which usually focus on three interrelated themes:

- Sanctions. The system of roles is accompanied by a system of punitive sanctions that are among the primary mechanisms of social control. These sanctions affect those who do not meet expectations, thus demonstrating the power that society has over actors of roles insofar as the other individuals in a society judge appropriate individual role performance.

- Hierarchy. The differentiation of roles is related to a stratified hierarchy, and thus to a condition of social inequality in which the holders of different roles are caught in power relations of superiority and inferiority.

- Power conflicts. Some roles are in short supply and are not available to all who would wish to play them. Occupation of these roles then becomes the subject of power conflicts, disputes over the legitimacy of relevant structures, and even violent conflicts. Social roles can be the subject of identification for individual human beings (in particular if one plays a role that one likes); yet equally they can be unsuited to the individual, who then tries to keep some distance from their role. Goffman's concept of "distance from the role" [Goffman 1961: 106-109; Urbánek 1979: 118-125; Jean-Pierre Junker 1971: 21-30] does not mean an open rejection of a specific role, but a certain kind of behaviour to indicate to others that the individual's personality and identity are not reducible to the particular role that due to certain circumstances they play or even have to play, but transcend this role. Goffman understands such a distance as often the only way to maintain dignity in conditions where we are forced to play a certain role by necessity. 
The German sociologist Uta Gerhardt understands the concept of role in terms of typification, and places it alongside Alfred Schütz's phenomenological sociology [Gerhardt 1971: 155-166]. Typification is encountered mainly in the form of standard, typical names for certain areas or manifestations of human behaviour. In this context, the social role (e.g. the role of shop assistant, conductor, teacher or clerk) can be defined as a specific social type and the typical behaviour associated with it. A significant typifying tool is language, which allows users to incorporate into their personal experience even things and events that they will never encounter or even come across. As much as typifying schemes make orientation in the everyday world easier, they may equally be burdened with simplifications, prejudices and stereotypes. In this case, the names of typical roles then become a kind of "label" to describe not only institutionalized but also deviant behaviour. Lundberg, Schrag and Larsen [1967: 358] in this context mention that giving a certain person such a label may lead eventually to this person starting to act according to the expectations associated with it, i.e. that deviant behaviour can be a consequence of expectations of behaving deviantly.

American sociologist Anselm L. Strauss was the author of Mirrors and Masks: The Search for Identity [Strauss (1959) 1974], in which he raised the question of why people in contact with others put on "masks", and what is hidden behind these masks. A mask can cover the true face of the person: it can disguise one's identity, but it may also provide concealment and protection. Through the metaphor of the mask, it became possible to view the social role as a means for hiding the individual's true face and identity. The Czech sociologist Eduard Urbánek [1979: 94-96] in Masks, roles, characters shows that this may also become an excuse through which people avoid personal responsibility for how they have behaved or currently are behaving. Noteworthy examples are the minions of organised-crime systems or dictatorships, where many people who served them do not want to admit personal guilt for what they did, and pass on all responsibility to higher social interests, official duties and superiors, claiming that they themselves were only fulfilling orders. In other words, the responsibility for their deeds is transferred to those institutions that laid down the rules for their roles.

As noted earlier, a special position in the discussions on the issue of roles is occupied by Ralf Dahrendorf's concept of Homo sociologicus, expressed first in his journal article in 1958 (Kölner Zeitschrift für Soziologie und Socialpsychologie, Vol. 10., No. 2, 3), and later as a book [Dahrendorf 1964], subsequently repeatedly re-published, translated into many languages and still read and commented on [e.g. Nixdorf 2011; Kneidinger 2013].

The core of Dahrendorf's problem is that human individuals for most of their lives play social roles associated with social determination, constraint and pressure to conformity. If they play these roles in the required manner, as is expected of them, they are accepted and rewarded. On the other hand, when they do not fulfil these expectations, they are punished, excluded, and may be subjected even to penal sanctions [Dahrendorf 1964: 28 ff.]. In such a world, Dahrendorf asks, where is there a place for human freedom, autonomy and creativity - a question, it must be said, that he leaves unanswered.

One response to Dahrendorf's question was offered by American sociologist Peter L. Berger in his work Invitation to Sociology: A Humanistic Perspective. Berger admits that the world of social roles evokes a kind of enormous prison in which human behaviour is hampered by socially mandatory roles, whose observance is intimately linked with all sorts 
of mechanisms of social control. In such a world, Berger adds, we are trapped in our own efforts [Berger 1991: 106]. Usually, our playing a role is not even consciously realized, as they are approached automatically as if entirely obvious. Often they may not even be forced on us, because we accept them willingly, even with enthusiasm, as it is advantageous and rewarding to do so [Urbánek 1979: 114].

Inspired by Helmuth Plessner, Berger nonetheless finds ways, even within this world, for people to prove that the external coercive power of society is not all-powerful and they are not powerless enactors of forced roles. Having stated that the world of roles resembles a prison, Berger immediately reverses the terms of the argument with the claim that human individuals can demonstrate their freedom not outside of the world so described, but paradoxically only within it. The compelling forces of society are not omnipotent and human individuals are not powerless against them. According to Berger [1991: 112-117], human individuals can demonstrate their freedom by manipulating the roles they should play, or even transforming them (i.e. modifying the roles' content and the expectations associated with them). They can also - as shown by E. Goffman - hold themselves at a distance from their role, and ultimately even refuse to play certain roles, though this final stance can have the gravest consequences.

In Berger's approach, freedom is understood primarily as the opportunity for personal choice and innovative action within the world of roles - a matter understandably not only for theoretical speculation, but even for empirical observation. Louis A. Zucher [1983] for instanced tried in his research to analyze the procedures through which people familiarize themselves with roles and change their content (assimilation, modification, transformation and dealing with unacceptable roles etc.).

From the perspective of Berger's considerations, one can conclude that the problem posed by Dahrendorf is in fact something of an artificial construction, in the sense of a deliberate emphasis and absolutization of only one aspect: namely, that the role affects the individual through pressure. Omitted from Dahrendorf's characterization is any sense that this pressure is not omnipotent, and that within the rules and requirements of the role and role playing there exists "space" that allows for the individual as a free human being. Man is not a simple machine or automaton to play roles like a gramophone record on a record-player; much more is taking place in role-enactment than the simple transcription of role regulations into lived practice. The concept of "playing a social role" reflects a much richer and more complex content. Role playing does not depend only on the types of expectations associated with the role, but also on the seriousness of those expectations, on the personality of the actor and its opponents, and on the character of the situation in which all this occurs. In the course of playing a specific social role, in most cases the actor must interconnect and "balance out" a number of conditions and influences, many of which greatly exceed the extant content by which the role is defined.

\section{Homo duplex and the AGIL Scheme}

The key problem of Dahrendorf's theoretical construction of Homo sociologicus lies first and foremost in its presentation of the human subject as a being fully subordinated to, and fully controlled by, social forces. This construction is problematic especially because it leaves no space for human freedom, creativity and autonomy. Moreover, even within 
the conception of Homo sociologicus, Dahrendorf indicates an implicit assumption that the human personality does not consist only of its accepted and performed roles, but also involves some additional, individualistic part of the human self. As such, personality must be understood as a more complex whole which cannot be reduced to its primary, i.e. social aspects, because there is always a second and contradictory dimension which has its own needs. Hence, even within this reductive schema we arrive at the outline of a person who is not reducible to social roles, because these are only one part of the human self. One thinker who drew such a dualistic picture of human existence was Emile Durkheim, who uses the term "Homo duplex" [Durkheim (1914) 1995] to show that the human being is not reducible to a restricted set of social demands, because they are only one part of the human self, which is internally divided in a contradictory way.

Durkheim states that every person possesses two kinds of consciousness, two aspects of psychic life: the personal and the non-personal [Durkheim 1995: 30-31; Šubrt 2015: 18-19]. Our physical body, on the one hand, is a source of unceasing wishes and desires of our egoism. Our socialized being, on the other, is a product of society as it lives and acts through us, and furthermore monitors and restricts the expressions of our egoism through internalized social requirements.

Similar approaches are present in the works of other classical sociologists as well. According to Georg Simmel, the human being is split and remarkably ambivalent in its nature. In his essay "Brücke und Tür", Simmel describes the situation of the human being as at one and the same time outward-oriented, attracted to society and association with other people, while remaining a world in itself, longing for autonomy, independence and distance from others (1909) [Simmel 1957: 1-7]. William I. Thomas and Florian Znaniecki made a distinction between two components of human personality: temperament and character - the former being naturally constituted, the latter socially formed [Thomas-Znaniecki 1958: 1844-1846]. George Herbert Mead outlines a theory of the human "Self" as an ambivalent unity of two dimensions, "I" and "Me" [Mead 1977: 209-246]; "I" being the individual, subjective component, which is active and creative, "Me" being the objective and passive component, formed by the internalized attitudes of the social group or society to which the individual belongs.

However, an even more complex picture of the human individual than that offered by the dualistic conceptions of Durkheim, Simmel or Mead can be derived from Talcot Parsonons' theory of action based on the AGIL scheme [Parsons 1971: 55]..$^{2}$ If we apply Parsons's model of action to the characteristics of the actor (i.e. the player of social roles), we can distinguish four distinct components: A) the condition of the biological organism (of the body); G) the state of the psyche; I) society internalized in the process of socialization; L) learned culture.

If we compare the previous two-component model of Homo duplex and Parsons's fourcomponent model of the AGIL actor, we might think it possible to merge these two models. At first glance, it might seem that such a combination would be easily achieved if we conflate the biological organism and the psyche with the egoistic part, and if culture and

\footnotetext{
2 Any social system, according to Parsons, can endure only if it ensures the implementation of four basic functions, which are: adaptation (A), achieving goals $(\mathrm{G})$, integration (I) and maintenance of latent cultural patterns (L).
} 
society are placed, correspondingly, with the internalized social requirements. Yet the actual result is much more complicated. The interconnection of the model of Homo-duplex with a model based on the scheme of AGIL leads to a still more detailed and structured image of the human actor, which can be shown in the form of a table with eight fields (Table A).

Table A: The interconnection of the Homo duplex model with a model based on schematic AGIL

\begin{tabular}{|c|c|c|}
\hline \multirow{2}{*}{ AGIL of the Actor } & \multicolumn{2}{|c|}{ Homo duplex } \\
\hline & Individualism/Egoism & Sociability/Altruism \\
\hline $\begin{array}{c}\text { Biological } \\
\text { Organism (Body) }\end{array}$ & $\begin{array}{l}\text { subjectively perceived needs } \\
\text { of the body } \\
\text { (e.g.: not to have health } \\
\text { problems) }\end{array}$ & $\begin{array}{l}\text { subjectively reflected societal demands } \\
\text { on the body } \\
\text { (e.g.: to have the physical prerequisites } \\
\text { for military service) }\end{array}$ \\
\hline Psyche & $\begin{array}{l}\text { subjectively perceived needs } \\
\quad \text { of the psyche } \\
\text { (e.g.: to experience enjoyable } \\
\text { and exciting psychic states) }\end{array}$ & $\begin{array}{l}\text { subjectively reflected societal demands } \\
\text { on the psyche } \\
\text { (e.g.: to have the psychic prerequisites } \\
\text { for the performance of a demanding } \\
\text { profession) }\end{array}$ \\
\hline $\begin{array}{c}\text { Internalized } \\
\text { Society }\end{array}$ & $\begin{array}{l}\text { subjectively perceived needs } \\
\text { in relation to society } \\
\text { (e.g.: have a respected and } \\
\text { admired position in society) }\end{array}$ & $\begin{array}{l}\text { subjectively reflected demands of society } \\
\text { (e.g.: to perform satisfactorily tasks } \\
\text { which society puts in front of the } \\
\text { individual) }\end{array}$ \\
\hline Learned Culture & $\begin{array}{l}\text { subjectively perceived needs in } \\
\text { relation to relation to culture } \\
\text { (e.g.: self-realization through } \\
\text { artistic expression) }\end{array}$ & $\begin{array}{l}\text { subjectively reflected demands of culture } \\
\text { (e.g.: accept cultural traditions } \\
\text { and customs) }\end{array}$ \\
\hline
\end{tabular}

The underlying principle for this model is the idea that each component of the AGIL scheme is viewed from the duplex perspective: i.e. both on the level of perceived individual/egoistic needs and the level of reflected social requirements. Each of the eight "boxes" represents one of the areas of human motivation and attitude formation that are reflected in human action and the performance of social roles. Its great advantage is its higher complexity compared with the separate ideas of Homo sociologicus or Homo duplex. Although it is in itself complex enough, it could become even more complex if we further divide the body, psyche, society and culture into individual sub-systems. It is necessary to admit, however, that for a number of sociological analyses this eight-component model is too unwieldy, complex and detailed. For example, in conceptions and explanations based on the concept of rational choice, all of these eight dimensions are simply replaced by one dimension, the dimension of economic rationality (based on a comparison of costs and returns). Even if our theoretical model excels in revealing the complexity of the assumptions on which human action and the playing of social roles is based, we must admit that for a number of research tasks its high level of detail places it at a disadvantage.

Understanding the essence of the problem presupposes a clear realization of the difference between the understanding of social role as a set of rules, regulations and expectations for a particular type of conduct, and the actual playing, performance or enactment of such 
a role, where we can find not only conformity to the rules, regulations and expectations, but also voluntarism, subjectivity, creativity, personal preferences, or even lack of discipline. Put briefly: role playing is a very complex system of actions, and it is our conviction that this complexity can be captured and analyzed through a theoretical model that links the concept of Homo duplex together with the AGIL-scheme.

\section{Role playing - a concept to aid in resolving the relationship between individualism and holism}

Even though the concept of social role continues to be encountered in sociological literature today, the most fervent discussions of it largely came to an end during the 1970's [Haug 1972; Jackson 1972; Joas 1973; Griese - Nikles - Rülcker 1977; Wiswede 1977; Biddle in 1979], in good measure because other approaches and topics pushed interest in it to the sidelines. This change was not merely a temporary shift in the tides of sociological fashion but reflected a deeper change, namely the rejection of holistic, structural functionalist ideas of the human individual as a more or less passive and conformist performer of structural requirements and functional imperatives, and a re-orientation toward the concept of the human actor as an autonomous, separate and independent being who decides and acts on the basis of knowledge, preferences and rationality, following interests, aims and objectives. Turning away from the human subject purely as Dahrendorf's Homo sociologicus, the image of the individual for sociology assumed a different form: the socially determined and controlled performer of roles was replaced by the notion of a sovereign, independently thinking and acting actor, gifted with will, knowledge and creativity.

Anthony Giddens, who in the 1970s and 80s criticized what he described as the "orthodox consensus" in Parsons' work, expressed the opinion that social theory must deal primarily with the issue of human actors. Judging from Giddens's discussion of human individuals in his theory of structuration, we can assume the idea of a competent, knowing and self-confident actor (Giddens' "agent") as an active, relatively autonomous, qualified and competent executor of social activities. In other words, the sociological subject is a human being gifted with reflection and self-reflection and the capacity to understand what they do while doing it [Giddens, 1997: 36].

Another approach was offered by the emergence of rational choice theory, which as previously indicated - propounded the picture of the social individual who expresses individual preferences and rationally decides to minimize costs and maximize profits. In this case, individual behaviour is associated with rationality via economic and mathematical methods. Rational-choice theory mainly featured in the interdisciplinary approach in American sociology through James S. Coleman [1994], in France through Raymond Boudon [1980], and in Germany through Hartmut Esser [1993].

Pierre Bourdieu's elaboration of this has gained and retained great popularity up to the present day. According to Bourdieu, social agents are equipped with systematically structured dispositions constitutive for practice and thinking about this practice. This set of dispositions (inclinations) to seeing, thinking and behaving in society Bourdieu describes as habitus. Habitus are schemes of perception, thought and action common to all members of the same group or class [Bourdieu 1998: 13-16]. 
Interest within the professional community was also stimulated by Bruno Latour [1996], who in his Actor-Network Theory (ANT) shows that networks of interactions in which human agents are involved can activate not only the people themselves but also certain non-human, non-living objects. Another very hotly discussed topic has become the question of personal identity, constituted through narrative approaches based on the assumption that a major formative factor of identity is the means through which people become the subject of their own story [Ricoeur 1991]. Nor too should the theory of the creative action by Hans Joas [1992] be left out, as it addresses the human creative abilities that allow human agents to create and change social reality, or the theory of performativity of Jeffrey Alexander [2006], which - itself inspired by the theatre - puts an emphasis on publicly staged/displayed action while distancing itself from the previous theory of social roles. Finally, one cannot overlook the particular emphasis increasingly placed on human emotions in sociological research in recent decades [Turner - Stets 2005], or the ambitious demands for the interpretation of human behaviour leading to increased intellectual contact with disciplines outside sociology, building on natural-scientific bases such as ethology, socio-biology and evolutionary psychology.

As this extensive list of issues makes clear, the theme of roles been been significantly pushed away from the centre of attention: now, the question is whether it is worthwhile coming back to, and if so, how. The author of this paper believes that specific reasons exist for re-considering it, related to the problem dealt with in his previous work [Šubrt 2012; Šubrt 2015], the themes of which are only briefly indicated here. Essentially, a concept of the playing of social roles could be useful from a theoretical standpoint simply because it allows us to link together the two poles of sociological thinking, individualism and holism.

In the current theoretical efforts toward overcoming this conflict, the present author has already identified two basic strategies [Šubrt 2015: 13-14]. The first is based on postulating a third aspect between the individual and society as a keystone to connect both poles. The second strategy is the effort to bring the two poles - individual and collective - as near together as possible and put them into a single explanatory framework so that in the explanation of social actions both individualistic and holistic perspectives are alternated.

The first approach can be found in Georg Simmel, for whom the intermediary "linkage" was the concept of Wechselwirkung [Simmel 1968: 14-16] i.e. interaction, or as in Norbert Elias with the concept of figuration, understood as a mesh of interpersonal relationships [Elias 1992]. A typical example of the second approach is Anthony Giddens and his theory of structuring, in which the individual pole is represented by the concept of "action" and the social pole by "structure". Giddens's theory is based on the theory of the duality of actions and structures, where structures are described as the product of human action, which once formed create the preconditions for subsequent human actions, both allowing as well as guiding and limiting [Giddens 1997: 67-90]. Both briefly outlined strategies are not so different from each other; on the contrary, they are complementary, with various points of overlap.

To return to the issue of roles: they have a major explanatory potential, in moving individualism and holism as close as possible to each other and interconnecting them in a convincing way, contributing to overcoming the gulf between these two directions of sociological thinking. 
To this end, we must first distinguish the concept of "social role" from what can be described as "playing a social role", which (as already mentioned) is a concept broader and more complex than social role itself. As an action, role playing encompasses a very complex reality, for the explanation of which we might utilize the current paper's proposed theoretical model combining the concept of homo duplex with the AGIL-scheme (see the table A). Role-playing is connected with and dependent on a number of factors, which include the way in which the individual has mastered the appropriate role, the personal qualities and abilities that they are able to devote to it; their own (self-centred) interests achieved through playing; the way their team-mates react and play their roles, and finally also the situation in which behaviour in the role occurs. Consequently, role-playing is significantly greater than the set of rules, regulations and standards that characterize the role itself. The actor of a social role faces a number of different requirements and expectations and must try by performance to bring them into correspondence.

In conclusion, we can assume that "social role playing" reflects the sought-after "third" element to connect the individual and society, and in conjunction with this, human behaviour and social structure. At the same time, it is the element that brings the opposing poles of holistic/individualist theory towards each other to the maximum extent, because in playing the role we see both one's individuality and the interests of the community. Role playing is what aligns individual goals, wishes, and preferences, with societal demands, structural pressures and functional imperatives. In addition, role playing figuratively expresses a "transmission" between the theoretical oppositions of the individual and society. It seems that the sociological theme of roles contains a potential that remains untapped, and thus merits our attention.

\section{Bibliography}

Alexander, Jeffrey C. [2006]. Cultural Pragmatics: Social Performance between Ritual and Strategy. In. Alexander, Jeffrey C. - Giesen, Bernhard - Mast, Jason L. Performance, Symbolic Action, Cultural Pragmatics, and Ritual. Cambridge: Cambridge University Press, pp. 29-90.

Berger, Peter L. [1991]. Pozvání do sociologie. Prague: FMO.

Berger, Peter L. - Luckmann, Thomas [1999]. Sociální konstrukce reality: Pojednání o sociologii vědèní. Brno: Centrum pro studium demokracie a kultury.

Biddle, Bruce J. [1979]. Role Theory: Expectations, Identities, and Behaviors. New York: Academic Press.

Boudon, Raymond [1980]. Die Logik des gesellschaftlichen Handelns: Eine Einführung in die soziologische Denk- und Arbeitsweise. Neuwied: Luchterhand.

Bourdieu, Pierre [1998]. Teorie jednání. Prague: Karolinum.

Claessens, Dieter [1970]. Role und Macht. Munich: Juventa Verlag.

Coleman, James S. [1994]. Foundations of Social Theory. Cambridge, Massachusetts: The Belknap Press of Harvard University Press.

Dahrendorf, Ralf [1963]. Gesellschaft und Freiheit: Zur soziologischen Analyse der Gegenwart. Munich: Piper.

Dahrendorf, Ralf [1964]. Homo sociologicus: Ein Versuch zur Geschichte, Bedeutung und Kritik der Kategorie der sozialen Rolle. 4th ed. Cologne - Opladen: Westdeutscher Verlag.

Davis, Kingsley - Moore, Wilbert E. [1945]. Some Principles of Stratification: A Critical Analysis. American Sociological Review 10 (2): 242-249.

Dreitzel, Hans P. [1980]. Die gesellschaftlichen Leiden und Leiden an der Gesellschaft. Stuttgart: Ferdinand Enke 1980.

Durkheim, Émile [(1914) 1995]. Dualismus lidské přirozenosti a její společenské podmínky. In. Antropologie, sociologie, historie. Cahiers du CEFRES, No. 8, pp. 16-34. 
Elias, Norbert [1992]. Figuration. In. Schäfers, Bernhard (ed.). Grundbegriffe der Soziologie. 3rd. ed. Opladen: Leske-Budrich, pp. 90-92.

Elias, Norbert [2006]. Spoločnost' indivíduí. Bratislava: Kalligram.

Eisermann, Gottfried [1991]. Rolle und Maske. Tübingen: J. C. B. Mohr (Paul Siebeck).

Esser, Hartmut [1993]. Soziologie: Allgemeine Grundlagen. Frankfurt, New York: Campus Verlag.

Gerhardt, Uta [1971]. Rollenanalyse als kritische Soziologie: Ein konzeptueller Rahmen zur emprischen und methodologischen Begründung einer Theorie der Vergesellschaftung. Neuwied: Luchterhand.

Gerth, Hans - Mills, C. Wright [1970]. Person und Gesellschaft: Die Psychologie Sozialer Institutionen. Frankfurt am Main: Athenäum.

Giddens, Anthony [1997]. Die Konstitution der Gesellschaft: Grundzüge einer Theorie der Strukturierung. 3rd ed. Frankfurt am Main: Campus.

Goffman, Erving [1961]. Encounters: Two Studies in the Sociology of Interaction. Indianapolis: Bobbs-Merill.

Goffman, Erving [1999]. Všichni hrajeme divadlo: Sebeprezentace v každodenním životě. Prague: Nakladatelství Studia Ypsilon.

Griese, Hartmut M. - Nikles, Bruno, W. - Rülcker, Christoph [1977]. Soziale Rolle: Zur Vermittlung von Individuum und Gesellschaft; Ein soziologisches Studien- und Arbeitsbuch. Opladen: Leske + Budrich.

Habermas, Jürgen [1981]. Theorie des kommunikativen Handelns, Band 1, 2. Frankfurt am Main: Suhrkamp.

Haug, Frigga [1972]. Kritik der Rollentheorie und ihrer Anwendung in der bürgerlichen deutschen Soziologie. Frankfurt am Main: Fischer Taschenbuch Verlag

Jackson, John A. (ed.) [1972]. Role. Cambridge: Cambridge University Press.

Joas, Hans [1973]. Die gegenwärtige Lage der soziologischen Rollentheorie. Frankfurt am Main: Athenäum. Joas, Hans [1992]. Die Kreativität des Handelns. Frankfurt am Main: Suhrkamp.

Junker, Jean-Pierre [1971]. Entfremdung von der Rolle: Ein Nachtrag zu Goffmans Konzept der Rollendistanz. Bern: Paul Haupt.

Kneidinger, Bernadette [2013]. Der Mensch als "homo sociologicus". In. Kneidinger, Bernadette. Geopolitische Identitätskonstruktionen in der Netzwerkgesellschaft. Wiesbaden: Springer, pp. 26-32.

Langer, Günter [1980]. Die Rolle in Gesellschaft und Theater. Oberwil bei Zug: Rolf Kugler.

Latour, Bruno [1996]. On Actor-Network Theory: A Few Clarifications. Soziale Welt 47: 369-381.

Linton, Ralph [(1936) 1964]. The Study of Man: An Introduction. New York: Appleton-Century-Crofts.

Lundberg, Georg A. - Schrag, Clarence, C. - Larsen, Otto N. [1967]. Sociologie (Revidované vydání, výňatky). Prague: Ústav marxismu-leninismu pro vysoké školy.

Mead, George H. [1977]. On Social Psychology. Chicago: The University of Chicago Press.

Merton, Robert K. [1977]. Der Rollen-Satz. In. Griese, Hartmut M. - Nikles, Bruno, W. - Rülcker, Christoph. Soziale Rolle: Zur Vermittlung von Individuum und Gesellschaft; Ein soziologisches Studien- und Arbeitsbuch. Opladen: Leske + Budrich, pp. 67-73.

Merton, Robert K. [2000]. Sociální struktura a anomie. In. Merton, Robert K. Studie ze sociologické teorie. Prague: SLON, pp. 132-177.

Moreno, Jakob Levy [1977]. Psychodrama. First Volume (fourth edition with new instroduciton). Beacon, N.Y.: Beacon House.

Nixdorf, Katja [2011]. Homo Sociologicus vs. Rollen-Set - Welches Modell ist besser geeignet um soziales handeln zu erklaren? Munich, Ravensburg: GRIN.

Parsons, Talcott [(1937) 1966]. The Structure of Social Action: A study in Social Theory with Special Reference to a Group of Recent European Writers. New York: The Free Press.

Parsons, Talcott [(1951) 1966]. The Social System. New York: Free Press.

Parsons, Talcott [1968]. Beiträge zur soziologischen Theorie. Neuwied am Rhein, Berlin: Luchterhand.

Parsons, Talcott [1971]. Společnosti: Vývojové a srovnávací hodnocení. Prague: Svoboda.

Ricoeur, Paul [1991]. Narrative Identity. In. Wood, David (ed.). On Paul Ricoeur: Narrative and Interpretation. London: Routledge, pp. 188-199.

Simmel, Georg [1957]. Brücke und Tür: Essays des Philosophen zur Geschichte, Religion, Kunst und Gesellschaft. Stuttgart: K. F. Koehler.

Strauss, Anselm [(1959) 1974]. Spiegel und Masken: Suche nach Identität. Frankfurt am Main: Suhrkamp.

Schulte-Altedorneburg, Manfred [1977]. Rollentheorie als Soziologie der Herrschaft. Frankfurt am Main: Campus. 
Šubrt, Jiří [2012]. Individualismus versus holismus: Nástin pokusu o řešení teoretického dilematu. Sociální studia (Sociologická teorie) 9 (1): 29-44.

Šubrt, Jiří [2015]. The Society of Individuals: How to Solve the Dilemma of Individualism and Holism in Historical Sociology. Historická sociologie 2015 (1): 9-23.

Thomas, William I. - Znaniecki, Florian [1958]. The Polish Peasant in Europe and America. Volume two. New York: Dover Publications.

Turner, Jonathan H. - Stets, Jan E. [2005]. The Sociology of Emotions. Cambridge: Cambridge University Press.

Urbánek, Eduard [1979]. Marxismus v konfrontaci s buržoazní koncepcí sociální role: Role, masky, charaktery. Prague: Univerzita Karlova.

Wiswede, Günther [1977]. Rollentheorie. Stuttgart: Verlag W. Kohlhammer.

Zurcher, Louis A. [1983]. Social Roles: Conformity, Conflict, and Creativity. Beverly Hills: Sage.

Jiř́ Šubrt ("1958) studied sociology and economics in the 1980's at Charles University in Prague. Since 1990 he has lectured at this university at the Faculty of Arts. In 2009, he founded and has since been leader of the Department of Historical Sociology at the Faculty of Humanities. He is the author and editor of several books published in the Czech language, which mainly deal with the theme of contemporary sociological theory, particularly with regard to issues of action, structure and social systems. Over the longer term he has also paid attention to the issues of time and memory, recently implementing a three year project focused on the empirical research of the historical consciousness of the Czech population. In the area of historical sociology he has focused on the problems of the civilization process, civilizational comparative analysis, social change and multiple modernities. 